\title{
Sanksi Pidana terhadap Guru yang Melakukan Tindak Penganiayaan kepada Murid saat Proses Pembelajaran
}

\author{
Anak Agung Ngurah Adhi Wibisana, I Made Sepud, I Made Minggu Widyantara \\ Fakuktas Hukum Universitas Warmadewa, Denpasar-Bali, Indonesia
}

\begin{abstract}
Abstrak
Indonesia memiliki Undang-Undang tentang bidang pendidikan yaitu Undang-Undang Nomor 14 Tahun 2005 tentang Guru dan Dosen. Dalam pemberlakuannya, terdapat suatu kasus yang menyebabkan pro-kontra terhadap pernyataan setiap pasal UU Guru dan Dosen, terutama terkait adanya hak membela diri dalam tindak pidana penganiayaan. Tujuan penelitian ini yaitu mengetahui pengaturan metode pengajaran terhadap murid saat proses pembelajaran dan mengetahui sanksi pidana terhadap guru yang melakukan penganiayaan kepada murid saat proses pembelajaran. Penelitian ini menggunakan metode normatif dengan sumber data utama yaitu hukum dan Undang-Undang. Hasil penelitian menunjukan bahwa unsur adanya perbuatan, dan/atau adanya akibat perbuatan, rasa sakit pada tubuh, serta luka pada tubuh yang terdapat dalam Pasal 351 ayat (1) KUHP mengacu pada UU Guru dan Dosen, yaitu dalam Pasal 77 ayat (6). Pasal ini mengartikan dasar mengenai penganiayaan, yakni tindakan yang mengakibatkan timbulnya rasa sakit terhadap seseorang. Tindak pidana penganiayaan dalam dunia pendidikan, setidaknya harus dipertimbangkan dengan maksud mendisiplinkan dan mencerdaskan kehidupan bangsa.
\end{abstract}

Kata Kunci: Sanksi pidana guru; Penganiayaan

\begin{abstract}
Indonesia has a law on education, namely Law No. 14 of 2005 on Teachers and Lecturers. In its implementation, there is a case that causes pros and cons to the statement of every article of the Teacher and Lecturer Law, especially in relation to the right to defend oneself in criminal acts of persecution. The purpose of this research is to know the arrangement of teaching methods for students during the learning process and to know the criminal sanctions against teachers who abuse students during the learning process. This study uses a normative method with the main data sources namely laws and regulations. The results showed that the element of an act, and / or the result of an act, pain in the body, and injuries to the body contained in Article 351 paragraph (1) of the Criminal Code refers to the Teacher and Lecturer Law, namely in Article 77 paragraph (6). This article defines the basis of persecution, namely actions that cause pain to a person. The criminal act of persecution in the world of education, at least, must be considered with the intention of disciplining and educating the nation's life.
\end{abstract}

Keywords: Teacher criminal sanctions; Persecution

\section{PENDAHULUAN}

Semakin berkembangnya ilmu teknologi, memungkinkan masyarakat untuk lebih konsumtif dalam menggunakannya. Dewasa ini di dalam lingkungan masyarakat telah banyak terjadi segala bentuk tindakan menyimpang seperti kenakalan remaja yang dilakukan oleh anak-anak di bawah umur. Hal tersebut dikarenakan adanya faktor-faktor dari dalam, dimana kebebasan pertama-tama dibatasi oleh faktor dari dalam, baik fisik maupun psikis (Bertens, 1993). Strategi pembelajaran aktualisasinya berwujud serangkaian dari keseluruhan tindakan strategis guru dalam rangka mewujudkan kegiatan pembelajaran yang efektif dan efisien. Belajar mengajar sebagai suatu sistem mengacu pada pengertian sebagai seperangkat komponen yang saling bergantung satu sama lain untuk mencapai tujuan.

Selaku suatu sistem, belajar mengajar meliputi suatu komponen antara lain tujuan, bahan, siswa, guru, metode, situasi dan evaluasi. Agar tujuan tercapai, maka semua komponen yang ada harus diorganisasikan sehingga antar sesama komponen terjadi kerja sama, karena itu guru tidak boleh hanya memperhatikan komponen tertentu saja, tetapi harus mempertimbangkan komponen secara keseluruhan (Asrori, 2013: 172). Salah satu masalah pendidikan yang dihadapi adalah rendahnya 
mutu pendidikan pada setiap jenjang dan satuan pendidikan khususnya pendidikan dasar dan menengah. Berbagai usaha telah dilakukan, antara lain melalui berbagai pelatihan dan kualifikasi guru, penyediaan dan perbaikan sarana dan atau prasarana pendidikan, serta peningkatan mutu dan manajemen sekolah (Mustari, 2018: 241). Dalam hal ini, guru merupakan faktor penentu tinggi rendahnya kualitas hasil pendidikan. Namun demikian, posisi strategis guru untuk meningkatkan mutu hasil pendidikan sangat dipengaruhi oleh kemampuan profesional, faktor kesejahteraannya, faktor psikologis, dll (Mustari, 2018: 243). Dalam perspektif psikologi, jiwa manusia bersama raganya merupakan satu kesatuan (entitas) yang tidak dapat dipisahkan. Apa yang terjadi di dalam jiwa itu akan tampak di dalam raganya, selain itu kecepatan reaksi jiwa manusia dapat diukur pada kecepatan reaksi dalam gerak-gerik badannya (Prakoso, 2014: 39). Alam proses pembelajaran, murid atau siswa dituntut untuk dapat mengikuti serta memperoleh ilmu pengetahuan untuk dapat bersaing pada era Globalisasi dewasa ini.

Dewasa ini dalam dunia pendidikan banyak dijumpai adanya suatu perbuatan menyimpang tidak berlandaskan pada norma-norma hukum yang dilakukan oleh guru terhadap siswa pada saat proses pembelajaran berlangsung, seorang guru tanpa sengaja melihat ketidakdisiplinan yang dilakukan oleh beberapa siswa seperti halnya siswa bermain handphone disaat guru sedang menjelaskan pelajaran di depan kelas, dan dengan sengaja guru mencubit lengan siswa, sehingga menimbulkan rasa sakit dan trauma bagi siswa untuk mengikuti kembali proses pembelajaran.

Pada ketentuan Pasal 77 ayat (6) UU Guru dan Dosen, dimana tidak terdapat suatu ketentuan yang mengatur secara rinci terkait sanksi-sanksi pidana terhadap guru yang sewenang-wenang melakukan perbuatan menyimpang dari norma-norma hukum yang ada, selain itu apakah dengan adanya frasa hak untuk membela diri seorang guru yang melakukan tindak penganiayaan terhadap murid saat proses pembelajaran dapat terhindar dari sanksi pindana berdasarkan pada ketentuan dalam KUHP sesuai dengan kententuan Pasal 77 ayat (6) UU Guru dan Dosen. Berdasarkan latar belakang masalah yang telah diuraikan tersebut diatas, maka tujuan penelitian baru ini yaitu untuk mengetahui pengaturan mengenai metode pengajaran dan pembelajaran dan mengetahui sanksi pidana terhadap guru yang melakukan tindak penganiayaan kepada murid saat proses pembelajaran.

\section{METODE PENELITIAN}

Tipe penelitian yang digunakan dalam penelitian ini yaitu penelitian normatif. Soekanto \& Mamudji, 2018:14 menyatakan Penelitian hukum normatif merupakan penelitian yang dilakukan dengan cara meneliti bahan pustaka atau data sekunder belaka. Data yang digunakan dalam penelitian ini ada 2, yaitu data primer seperti UU dan data sekunder seperti buku-buku penelitian dan jurnal mengenai permasalahan dalam penelitian.

\section{HASIL DAN PEMBAHASAN}

Perkembangan zaman yang ditandai dengan adanya suatu kemajuan khususnya dibidang teknologi, hal tersebut berdampak pada dunia pendidikan baik positif maupun negatif. Datangnya media Massa, khususnya pada media elektronik yaitu menjadi sumber pengetahuan dan pendidikan pusat. Selain itu, sistem administrasi dalam lembaga pendidikan dapat lebih praktis dan lancar oleh adanya penerapan teknologi informasi dan komunikasi. Dengan adanya hal tersebut, memungkinkan lahirnya metode pengajaran dan pembelajaran yang baru bagi para peserta didik dan pendidik, dimana kemajuan teknologi tersebut dapat dengan mudah mengubah siswa agar mampu mengerti serta memahami materi yang bersifat abstrak disebabkan materi dapat diciptakan dengan adanya bantuan teknologi abstrak.

Guru sebagai teladan yang patut ditiru oleh para siswa baik diluar maupun didalam kelas, serta guru merupakan sebuah profesi bagi seseorang yang telah menyandang gelar sarjana. Profesi (profession) dimaksud dengan pekerjaan secara etimologi. Dewasa ini, ditemukan kenakalan yang dilakukan oleh para remaja. Hal tersebut tentunya dapat menghambat proses belajar-mengajar di dalam kelas. Nasution menyatakan antara lain, bahwa:

1. Mengajar merupakan pekerjaan dan tugas kompleks dan sulit. Oleh karena itu, tugas dan pekerjaan tersebut memerlukan persiapan dan perencanaan yang baik sehingga dapat mencapai hasil yang diharapkan 
2. Mengajar merupakan tugas yang harus dapat dipertanggungjawabkan. Dengan demikian, ia memerlukan suatu perencanaan dan persiapan yang mantap dan dapat dinilai pada akhir kegiatan proses belajar mengajar;

3. Mengajar merupakan tugas mengorganisasi dan mengatur jalannya proses belajar-mengajar. Oleh karena itu, setiap guru perlu membuat persiapan pengajaran atau satuan pelajaran sehingga dengan demikian ia dapat menggunakan dan mengatur alokasi waktu yang tesedia secara efektif dan efisien (Adriantoni, 2019).

Seorang guru pada saat proses pembelajaran, hendaknya menerapkan metode pengajaran yang sistematis dengan menggunakan prinsip-prinsip di dalam memilih atau menentukan teknik mengajar yang efektif. Bachtiar Riva'l mengemukakan bahwa:

1. Asas maju berkelanjutan (continuous progress) yang artinya memberi kemungkinan kepada murid untuk mempelajari sesuatu sesuai dengan kemampuannya;

2. Penekanan pada belajar sendiri, artinya anak-anak diberikan kesempatan untuk mempelajari dan mencari sendiri bahan pelajaran yang lebih banyak lagi daripada yang diberikan oleh guru;

3. Bekerja secara team, dimana anak dapat mengerjakan suatu pekerjaan yang memungkinkan anak untuk bekerja sama;

4. Multi disipliner, artinya memungkinkan anak-anak untuk mempelajari sesuatu dan meninjau dari berbagai sudut

5. Fleksibel, dalam arti dapat dilakukan menurut keperluan dan keadaan (Alma, 2012).

Adanya kenakalan remaja, menyebabkan suatu metode pengajaran tidak berlaku secara efektif lagi, dimana hal tersebut berdampak pada pembangunan pendidikan nasional kedepannya. Maka dari itu, pada saat dimulainya proses belajar dan mengajar hendaknya seorang guru memberikan ekstra perhatiannya terhadap salah satu murid yang dapat dikatakan kurang mendapatkan kasih sayang dari kedua orang tuanya.

Mendidik serta mengajar merupakan kegiatan yang selalu terikat pada tujuan, terarah pada tujuan dilaksanakannya demi mencapai tujuan. Jika dilihat berdasarkan jenjangnya, tujuan dari adanya pendidikan dapat dipilah menjadi tiga (Nana \& Ibrahim, 2010), yaitu:

1. Tujuan Institusional merupakan rumusan kualifikasi yang diharapkan dimiliki oleh setiap orang yang telah menyelesaikan pendidikan pada tingkat dan jenis lembaga pendidikan (sekolah) tertentu. Oleh karena itu, tujuan institusional SD lain dengan tujuan institusional SMP

2. Tujuan Kurikuler adalah tujuan yang pencapaiannya dibebankan pada masing-masing mata pelajaran. Tujuan pendidikan IPA, IPS, dan sebagainya merupakan tujuan dari kurikuler

3. Tujuan instruksional merupakan tujuan yang terbawah dari jenjang tujuan yang kita kenal. Tujuan ini merupakan tujuan yang hendak kita capai dalam setiap bagian mata pelajaran dengan apa yang kita ajarkan pada suatu sekolah tertentu.

Agar dapat melaksanakan suatu tugas pendidikan, maka seperti apa yang digariskan pada tujuan umum pendidikan diatas, hal tersebut dibebankan kepada lembaga pendidikan. Dengan demikian, diharapkan lembaga pendidikan agar dapat mengemban kewajibannya dengan baik. Terdapat suatu perumusan tujuan institusional dari lembaga pendidikan di Indonesia, antara lain seperti halnya pendidikan dan pengajaran taman kanak-kanak guna untuk menumbuhkan rohani serta jasmani kanakkanak sebelum menginjak ke sekolah rendah. Pendidikan dan pengajaran rendah yang bermaksud memberikan suatu kesempatan bagi mereka untuk mengembangkan bakat serta minat masing- masing dan memberikan dasar pengetahuan, ketangkasan serta kecakapan baik lahir maupun batin. Pendidikan dan pengajaran menengah guna untuk melanjutkan serta meluaskan suatu pendidikan disekolah rendah agar dapat mencapai cita-cita. Dan selanjutnya pendidikan dan pengajaran tinggi yang bermaksud untuk mempergunakan ilmu pengetahuan yang didapat di dalam suatu pendidikan guna memajukan kehidupan masyarakat luas. Untuk menentukan output dari pendidikan dapat tercapai dengan maksimal apabila tujuan dari pendidikan dijalankan dengan benar dan tepat. Sebelum menentukan suatu tujuan alangkah baiknya terlebih dahulu menentukan dasar dan atau landasannya. Yang menjadi landasan dalam pendidikan nasional antara lain landasan filosofis berasal dari Pancasila dan UUD NRI 1945, landasan sosiologis yang berasal dari masyarakat Indonesia, landasan kultural dimana berasal dari kebudayaan nasional, landasan psikologis yang berasal dari suatu perkembangan 
peserta didik, landasan ilmiah dan teknologi berasal dari perkembangan ilmu pengetahuan dan teknologi.

Pada dunia pendidikan, seorang guru juga harus mengutamakan tujuan dalam proses belajar mengajar merupakan suatu komponen pertama yang harus diterapkan dalam suatu proses pengajaran. Dalam hal ini tujuan yang dimaksud pada dasarnya merupakan suatu rumusan tingkah laku dengan kemampuan yang dapat diraih serta dimiliki oleh setiap siswa apabila telah menyelesaikan pengalaman dan kegiatan belajar dalam suatu proses pengajaran. Suatu tujuan pengajaran dapat diartikan menjadi salah satu bentuk upaya guru atau pendidik didalam hubungan berserta kewajibannya membina siswa atau peserta didik (Uzer Usman, 2017).

Adanya tujuan berawal dari suatu perencanaan yang baik, perencanaan merupakan suatu penerapan prinsip-prinsip umum mengajar tersebut untuk melaksanakan tugas mengajar dan perlunya interaksi antara guru dan murid baik di dalam maupun diluar kelas. Perencanaan melibatkan proses penetapan adalah keadaan suatu Massa depan yang diinginkan, dimana dilihat dari perspektif masa depan yang diinginkan perlu halnya membandingkan antara keadaan sekarang untuk kedepannya, sehingga seiring berjalannya proses dapat diketahui letak kesenjangan tersebut. Dalam hal ini, Kegunaan dari adanya perumusan terhadap tujuan metode pengajaran, antara lain:

1. Untuk menilai pengajaran, artinya suatu pengajaran dapat dinilai berhasil apabila siswa telah mencapai tujuan yang ditentukan

2. Membimbing siswa belajar, tujuan yang telah diberikan membimbing dan memberikan arah, acuan bagi siswa dalam melakukan kegiatan belajar

3. Sebagai bentuk kriteria dari perancangan pelajaran. Dengan tujuan pengajaran dapat menjadi dasar dan menentukan materi pelajaran

4. Menjadi media berkomunikasi dengan rekan guru lainnya. Dengan tujuan pengajarannya seorang guru dapat berkomunikasi dengan rekan gurunya mengenai apa yang hendak dicapai serta hal-hal apa yang sebaiknya dikerjakan oleh seorang guru (Uzer Usman, 2017).

Proses pembelajaran juga dapat diartikan sebagai bantuan yang diperoleh dari pendidik agar terjadi suatu proses dalam memperoleh ilmu pengetahuan, tabiat serta penguasaan kemahiran, pembentukan sikap dan kepercayaan dalam diri peserta didik. Suatu Kriteria keberhasilan guru dapat ditentukan melalui aktivitas siswa dalam mempelajari bahan pelajaran dan juga seberapa banyak materi yang telah dimengerti sehingga dapat mempengaruhi pola pikir dan tingkah laku para siswa. Hal-hal yang harus diperhatikan dalam mengembangkan kegiatan pembelajaran, sebagai berikut:

1. Kegiatan pembelajaran disusun untuk memberikan bantuan kepada para pendidik, khususnya guru agar dapat melaksanakan proses pembelajaran secara profesional;

2. Kegiatan pembelajaran memuat rangkaian kegiatan manajerial yang dilakukan guru, agar peserta didik dapat melakukan kegiatan seperti di silabus;

3. Kegiatan pembelajaran untuk setiap pertemuan merupakan skenario langkah-langkah guru dalam membuat peserta didik aktif belajar. Kegiatan ini diorganisasikan menjadi kegiatan: Pendahuluan, inti, dan Penutup. Kegiatan inti dijabarkan lebih lanjut menjadi perincian dari kegiatan ekplorasi, elaborasi, dan konfirmasi, yakni mengamati, bertanya, mengumpulkan informasi, mengasosiasikan, dan mengomunikasikan. Untuk pembelajaran yang bertujuan menguasai prosedur untuk melakukan sesuatu, kegiatan pembelajaran dapat berupa permodelan/ demonstrasi oleh guru atau ahli, peniruan oleh peserta didik, pengecekan dan pemberian umpan balik oleh guru, dan pelatihan lanjutan (Prastowo, 2017).

Perlunya perencanaan dalam proses pembelajaran yaitu guna dapat tercapainya perbaikan dalam pembelajaran. Perencanaan yang baik akan menentukan suatu hasil yang baik sebagai seorang guru yang dapat dikatakan profesional hendaknya harus melakukan sebuah perencanaan sebelum memulai kegiatan pembelajaran salah satu contohnya yakni dimana pembelajaran adalah proses kerja sama yang melibatkan antara guru dengan murid. Suatu pembelajaran mengandalkan segala potensi yang dimiliki oleh peserta didik guna menguasai suatu kompetensi yang diharapkan, untuk mendorong suatu pencapaian terhadap perilaku khusus demi mewujudkan masyarakat yang belajar. Agar proses pembelajaran berjalan secara optimal, pada dasarnya berawal dari langkah-langkah kegiatan yang berisikan pendahuluan dan atau kegiatan awal, kegiatan inti, dan kegiatan penutup, serta masingmasing disertai dengan alokasi waktu yang diperlukan. Untuk tercapainya tujuan dari proses pembelajaran, diperlukan suatu strategi guna memperlancar adanya tujuan tersebut. Yang dimaksud 
dengan strategi pembelajaran yakni suatu kegiatan pembelajaran yang harus dikerjakan guru dan siswa agar tujuan pembelajaran dapat dicapai secara efektif dan efisien (Sanjaya, 2008: 294).

Pada kondisi saat itu, maka akan ditemui semakin banyaknya bentuk penyimpangan norma hukum jika tidak dibarengi dengan amandemen undang- undang yang selaras terhadap perubahan sosial kehidupan masyarakat, maka dalam suatu upaya penegak hukum dapat kehilangan fungsi yang dapat mengakibatkan rendahnya kualitas hukum. Perbuatan hukum yang dilakukan didunia pendidikan merupakan suatu perbuatan yang diperbuat oleh seorang pendidik atau guru, dimana perbuatan hukum tersebut dilakukan pada saat proses pembelajaran maupun pengajaran.

Meningkatnya tindak pidana penganiayaan yang dilakukan oleh seorang guru terhadap peserta didik dalam dunia pendidikan telah banyak terjadi di Indonesia. Namun dikarenakan perangkat peraturan yang telah ada pada saat ini masih dianggap belum cukup kuat menjerat pelaku dengan sanksi yang tegas, selain itu juga dikarenakan adanya tindak kenakalan-kenakalan yang dilakukan baik anak maupun remaja didalam lingkungan sekolah. Maka seiring berjalannya waktu, dapat dipastikan perbuatan tersebut akan semakin berkembang di dalam dunia pendidikan dikemudian harinya. Akan tetapi seorang guru tak selamanya dapat menjaga wibawa dan citra sebagai seorang guru dimata anak didik dan masyarakat. Dimana masih terdapat sebagian guru yang mencemarkan wibawa dan citra guru. Pada media massa baik cetak maupun elektronik, sering diberitakan oknumoknum yang melakukan suatu tindakan asusila, asosial, dan amoral (Dahlan, 2018:15). Jika diperhatikan, para orang tua maupun seorang guru yakni memiliki anggapan bahwa mendidik serta mendisiplinkan anak harus dilakukan dengan cara kekerasan. Dalam hal ini, bagaimanapun alasannya bahwa segala bentuk tindak kekerasan yaitu tidak dibenarkan sesuai dengan ketentuan peraturan yang ada, apalagi perbuatan tersebut dilakukan oleh seorang guru kepada peserta didiknya.

Perilaku seorang guru yang melakukan tindak kekerasan merupakan suatu perbuatan yang tidak mencerminkan kompetensi kepribadian sehingga diragukan keguruannya. Dimana kompetensi kepribadian guru mempunyai indikator, yang diantaranya kepribadian yang mantap serta emosi yang stabil. Apabila masih terdapat seorang pendidik atau guru yang melakukan tindak pidana penganiayaan, selain dari adanya sanksi pidana berdasarkan ketentuan UU Perlindungan Anak, sanksi yang dapat digunakan selain itu yakni berdasarkan ketentuan sanksi administrasi pada Pasal 77 ayat (2) UU Guru dan Dosen, menyatakan sanksi sebagaimana dimaksud pada ayat (1), berupa teguran, peringatan tertulis, penundaan pemberian hak, penurunan pangkat, pemberhentian dengan hormat dan pemberhentian tidak hormat.

Dengan demikian, dari adanya sanksi-sanksi dari setiap ketentuan peraturan yang ada, maka setidaknya dapat mengurangi terjadinya suatu perbuatan menyimpang yang tidak berlandaskan pada norma hukum yang ada. Selain itu, berdasarkan ketentuan Pasal 351 KUHP mengenai sanksi pidana terhadap seseorang yang melakukan tindak penganiayaan, antara lain: "Penganiayaan diancam dengan pidana penjara paling lama dua tahun delapan bulan atau pidana denda paling banyak empat ribu lima ratus rupiah".

Pada pernyataan tersebut, tindak pidana penganiayaan yang sering kali ditemukan dalam dunia pendidikan yaitu berupa tindak pidana penganiayaan ringan yang dilakukan oleh seorang pendidik atau guru. Jika dilihat dari perspektif seorang guru pada dewasa ini didalam melaksanakan proses belajar maupun mengajar, terdapat suatu faktor yang menghambat terjadinya proses tersebut dimana salah satunya yaitu adanya faktor dari kenakalan yang dilakukan baik anak maupun remaja. Hal tersebut menjadi suatu penyebab terjadinya tindak penganiayaan yang dikarenakan adanya faktor gangguan psikis dari seorang guru, dimana seorang guru yang memiliki gangguan terhadap psikis rentan melakukan suatu perbuatan yang tidak berlandaskan pada norma hukum yang ada.

Selain itu, tujuan dari seorang guru melakukan tindak penganiayaan memiliki maksud tertentu yakni agar para peserta didik dapat disiplin dan menerapkan sikap sopan dan santun terhadap guru yang dikemudian hari dapat diterapkan dalam lingkungan masyarakat luas. Berbeda dengan seorang guru yang dengan sengaja tanpa memiliki alasan terntentu melakukan tindak penganiayaan kepada peserta didik yang memungkinkan adanya tindak diskriminasi terhadap salah satu peserta didik. Maka dari itu adanya suatu hak membela diri berdasarkan pada ketentuan Pasal 77 ayat (6) UU Guru dan Dosen, sangat diperlukan untuk melindungi seorang guru yang ingin mengubah setiap karakteristik peserta didiknya menjadi lebih baik lagi. Dalam hal ini, seorang guru yang terancam pidana berdasarkan pada ketentuan Pasal 351 KUHP, dapat mengajukan hak pembelaannya terhadap 
tindakan tersebut, dan memungkinkan seorang guru dapat terhindar dari adanya sanksi pidana dikarenakan hal tersebut dibenarkan.

\section{SIMPULAN DAN SARAN \\ 1. Simpulan}

Berdasarkan uraian di atas, dapat disimpulkan bahwa pengaturan metode pengajaran terhadap murid saat proses pembelajaran dapat dilakukan baik secara individual maupun berkelompok. Metode pengajaran yang dapat diterapkan oleh seorang guru yakni diantaranya metode yang bersifat luwes, fleksibel serta memiliki daya sesuai dengan watak siswa dan materi, selain itu juga metode yang dapat diterapkan pada saat proses pengajaran yang diantaranya seperti metode ceramah, metode tanya jawab, metode diskusi, dan lain sebagainya. Tujuan dari diadakannya suatu metode pengajaran secara umum yaitu agar peserta didik mendapatkan ilmu pengetahuan, serta mengetahui konsep dan teori pada saat proses pengajaran. Selain itu, tujuan dari adanya suatu pembelajaran yakni guna memberikan suatu pengalaman belajar dimana melibatkan proses mental dan fisik dengan interaksi antar peserta didik, dan peserta didik dengan guru, lingkungan, serta sumber lainnya dalam rangka pencapaian kompetensi dasar. Kemudian, sanksi yang dapat digunakan terhadap guru yang melakukan tindak pidana penganiayaan antara lain dapat berupa sanksi administrasi maupun sanksi pidana, sebagaimana diatur di dalam ketentuan pasal 77 UU Guru dan Dosen, Pasal 80 UU Perlindungan Anak maupun Pasal 351 KUHP. Dalam hal ini, sanksi administrasi yang dimaksud berupa teguran, peringatan tertulis, penundaan pemberian hak guru, penurunan pangkat, pemberhentian dengan hormat, dan pemberhentian dengan tidak hormat. Sedangkan sanksi pidana yang dimaksud berupa pidana penjara paling lama dua tahun delapan bulan atau pidana denda paling banyak empat ribu lima ratus rupiah, dan pidana penjara paling lama 3 (tiga) tahun 6 (enam) bulan dan/ atau denda paling banyak Rp. 72.000.000,00 (tujuh puluh dua juta rupiah). Untuk mewujudkan suatu pendidikan nasional yang bermutu, maka sangat diperlukan adanya kedisiplinan terhadap peserta didik. Maka dari itu seorang guru dituntut untuk dapat menciptakan peserta didik yang memiliki karakteristik sesuai dengan cita-cita bangsa selain dari mencerdaskan kehidupan bangsa. Penganiayaan dapat terjadi apabila kenakalan remaja semakin hari semakin meningkat, dalam hal ini guru dapat dikatakan sebagai korban maupun pelaku dari tindak pidana tersebut. Maka dari itu, dari adanya ketentuan Pasal 77 ayat (6) UU Guru dan Dosen yaitu terhadap adanya Hak Pembelaan Diri memungkinkan seorang guru dapat terhindar dari adanya sanksi pidana yang dikarenakan tugas dari seorang guru sangat berat dan selain itu masih terdapat suatu kenakalan yang disebabkan oleh anak maupun para remaja yang harus mendapatkan pendidikan khusus.

\section{Saran}

Melalui penelitian ini diharapkan bagi pemerintah sebagai pemegang hak regulasi, maka wajib untuk mengkaji ulang dari adanya UU Guru dan Dosen terkait ketentuan sanksi pidana, agar segala sesuatu bentuk tindakan yang menyimpang dapat teratasi tanpa adanya suatu kendala. Selanjutnya, bagi guru sebagai seorang pengajar atau pendidik hendaknya lebih berhati- hati dalam melakukan suatu tindakan mengingat metode pengajaran digunakan untuk mencerdaskan kehidupan bangsa yang mencakup kehidupan masyarakat luas. Maka sebagai pendidik, hendaknya membatasi diri agar tidak menjadi korban dari tindak pidana penganiayaan maupun menjadi pelaku dari tindak penganiayaan. Terakhir, kepada masyarakat khususnya pada pihak orang tua agar hendaknya mendidik anak terlebih dahulu didalam lingkungan keluarga, memberikan setiap anak kasih sayang tanpa terkecuali, tidak bertindak diskriminasi terhadap salah satu anak, serta melarang anak untuk tidak salah pergaulan didalam lingkungan sehari-hari, dimana agar anak tersebut terhindar dari adanya suatu kenakalan remaja yang berujung pada tindak penganiayaan yang dilakukan oleh seorang guru pada saat proses pembelajaran berlangsung.

\section{DAFTAR PUSTAKA}

Adriantoni, S. (2019). Profesi Keguruan (I). Depok: Rajagrafindo Persada.

Alma, B. (2012). Guru Profesional Menguasai Menguasai Metode dan Terampil Mengajar. Bandung: Alfabeta.

Asrori, M. (2013). Pengertian, Tujuan Dan Ruang Lingkup Strategi Pembelajaran. Madrasah: Jurnal Pendidikan Dan Pembelajaran Dasar, 5(2), 163-188. 
Bertens, K. (1993). Etika, Seri Filsafat Atmajaya: 15 (I). Jakarta: PT. Gramedia pustaka utama.

Dahlan, M. (2018). Menjadi Guru yang Bening Hati (I). Yogyakarta: Deepublish.

Mustari, M. (2018). Manajemen Pendidikan (3rd ed.). Jakarta: Raja Grafika Persada.

Nana, \& Ibrahim. (2010). Perencanaan Pengajaran (3rd ed.). Jakarta: PT. Rineka Cipta.

Prakoso, A. (2014). Hukum dan Psikologi Hukum. Yogyakarta: LaksBang Grafika.

Prastowo, A. (2017). Menyusun Rencana Pelaksanaan Pembelajaran Tematik Terpadu Implementasi Kurikulum 2013 untuk SD/MI (II). Jakarta: Kencana.

Sanjaya, W. (2008). Kurikulum dan Pembelajaran: Teori dan Praktik Pengembangan Kurikulum Tingkat Satuan Pendidikan (I). Jakarta: Prenadamedia Group.

Soekanto, S., \& Mamudji, S. (2018). Penelitian Hukum Normatif Suatu Tinjauan Singkat (18th ed.). Jakarta: Rajawali Pers.

Uzer Usman, M. (2017). Menjadi Guru Profesional (29th ed.). Bandung: Remaja Rosdakarya. 